\title{
Calcium-mediated perception and defense responses activated in plant cells by metabolite mixtures secreted by the biocontrol fungus Trichoderma atroviride

\author{
Lorella Navazio* $^{*}$, Barbara Baldan ${ }^{\dagger 1}$, Roberto Moscatiello ${ }^{1}$, Anna Zuppini ${ }^{1}$,
} Sheridan L Woo ${ }^{2}$, Paola Mariani ${ }^{1}$ and Matteo Lorito ${ }^{2}$
}

Address: ${ }^{1}$ Dipartimento di Biologia, Università di Padova, Via U. Bassi 58/B, 35131 Padova, Italy and ${ }^{2}$ Dipartimento di Arboricoltura, Botanica e Patologia Vegetale, Università di Napoli "Federico II", Via Università 100, 80055 Portici (NA), Italy

Email: Lorella Navazio* - lorella.navazio@unipd.it; Barbara Baldan - barbara.baldan@unipd.it;

Roberto Moscatiello - roberto.moscatiello@unipd.it; Anna Zuppini - zuppini@bio.unipd.it; Sheridan L Woo - woo@unina.it; Paola Mariani - marianip@bio.unipd.it; Matteo Lorito - lorito@unina.it

* Corresponding author †Equal contributors

Published: 30 July 2007

BMC Plant Biology 2007, 7:4| doi:10.1 |86/|47|-2229-7-4|
Received: 7 March 2007

Accepted: 30 July 2007

This article is available from: http://www.biomedcentral.com/I47I-2229/7/4 I

(c) 2007 Navazio et al; licensee BioMed Central Ltd.

This is an Open Access article distributed under the terms of the Creative Commons Attribution License (http://creativecommons.org/licenses/by/2.0), which permits unrestricted use, distribution, and reproduction in any medium, provided the original work is properly cited.

\begin{abstract}
Background: Calcium is commonly involved as intracellular messenger in the transduction by plants of a wide range of biotic stimuli, including signals from pathogenic and symbiotic fungi. Trichoderma spp. are largely used in the biological control of plant diseases caused by fungal phytopathogens and are able to colonize plant roots. Early molecular events underlying their association with plants are relatively unknown.

Results: Here, we investigated the effects on plant cells of metabolite complexes secreted by Trichoderma atroviride wild type $\mathrm{PI}$ and a deletion mutant of this strain on the level of cytosolic free $\mathrm{Ca}^{2+}$ and activation of defense responses. Trichoderma culture filtrates were obtained by growing the fungus alone or in direct antagonism with its fungal host, the necrotrophic pathogen Botrytis cinerea, and then separated in two fractions $(>3$ and $<3 \mathrm{kDa})$. When applied to aequorin-expressing soybean (Glycine max L.) cell suspension cultures, Trichoderma and Botrytis metabolite mixtures were distinctively perceived and activated transient intracellular $\mathrm{Ca}^{2+}$ elevations with different kinetics, specific patterns of intracellular accumulation of reactive oxygen species and induction of cell death. Both $\mathrm{Ca}^{2+}$ signature and cellular effects were modified by the culture medium from the knock-out mutant of Trichoderma, defective for the production of the secreted $42 \mathrm{kDa}$ endochitinase.

Conclusion: New insights are provided into the mechanism of interaction between Trichoderma and plants, indicating that secreted fungal molecules are sensed by plant cells through intracellular $\mathrm{Ca}^{2+}$ changes. Plant cells are able to discriminate signals originating in the single or two-fungal partner interaction and modulate defense responses.
\end{abstract}

\section{Background}

Trichoderma spp. are ubiquitous free-living soil fungi which act as biocontrol agents against several fungal phy- topathogens. They are commercially applied as biopesticides, thus limiting the abuse of chemical fungicides $[1,2]$. The antagonist activity of Trichoderma depends on multi- 
ple synergistic mechanisms, including a direct interaction with the pathogenic partner (mycoparasitism), as well as indirect mechanisms based on competition for space and nutrients $[3,4]$. Trichoderma strains are rhizosphere competent, i.e. able to grow in association with plant roots, and can actually penetrate the first few layers of plant tissues $[5,6]$. The effects of Trichoderma colonization on plants include an improvement of plant growth and metabolism, as well as the induction of systemic and localized resistance to phytopathogenic fungi, bacteria and viruses (reviewed by [4]). Even though the physiological changes concerning the plant as a whole and induced by Trichoderma spp. have been relatively well investigated, there are only few reports on the mechanisms through which plant cells perceive fungal metabolites secreted during biocontrol. These fungal molecules, which include proteins, peptides, oligosaccharides and antibiotics, act naturally in mixtures. The presence in the Trichoderma exudates of many classes of chemical components potentially acting as elicitors may explain the ability of this fungus to activate induced systemic resistance (ISR) virtually on any plant variety [7].

During plant-fungal interactions an extensive exchange of molecular messages occurs. Variation in cytosolic free $\mathrm{Ca}^{2+}$ concentration $\left(\left[\mathrm{Ca}^{2+}\right]_{\mathrm{cyt}}\right)$ is a well-known early component of signal transduction pathways involved in plantpathogen interactions $[8,9]$. Plants respond to pathogen attack through a rapidly induced $\left[\mathrm{Ca}^{2+}\right]_{\text {cyt }}$ elevation, which in turn initiates a cascade of reactions leading to activation of defense responses. No information is still available on the possible involvement of $\mathrm{Ca}^{2+}$ as second messenger in the mechanism of Trichoderma perception by plants.

In this paper we investigated plant cell responses, including intracellular $\mathrm{Ca}^{2+}$ variations, to Trichoderma metabolites released in the culture media of the fungus grown alone or in direct antagonism with a Botrytis cinerea strain susceptible to mycoparasitic attack by $T$. atroviride P1. In addition, we compared the effect of metabolite mixtures from both $T$. atroviride strain P1 wild type and a knock-out mutant of it, defective in the production of an endochitinase found to be important for biocontrol [10]. Our results indicate that plant cells are able to selectively perceive through $\mathrm{Ca}^{2+}$ messages macromolecule components of the fungal culture filtrates, released in the different experimental conditions. Specific $\left[\mathrm{Ca}^{2+}\right]_{\mathrm{cyt}}$ changes and levels of intracellular accumulation of reactive oxygen species (ROS), reduction in cell viability and occurrence of programmed cell death (PCD)/necrosis were detected.

\section{Results \\ Trichoderma metabolite mixtures activate a $\mathrm{Ca}^{2+}$ mediated signalling in soybean cells}

Fungal culture filtrates obtained from $T$. atroviride strain P1 wild type were tested on soybean cells stably expressing in the cytosol the bioluminescent $\mathrm{Ca}^{2+}$ indicator aequorin. In the $\mathrm{Ca}^{2+}$ measurement experiments fungal metabolite mixtures were applied to cells at a dose (4-fold concentrated culture medium) corresponding to that commonly used for in vivo bioassays of physiological effects (i.e. ISR and elicitor activity) on plants [10]. In preliminary doseresponse experiments, the above concentration was found to induce about half of the maximum effect on $\left[\mathrm{Ca}^{2+}\right]_{\mathrm{cyt}}$ increase (data not shown). The whole culture filtrate of Trichoderma elicited a strong $\mathrm{Ca}^{2+}$ elevation that was generated without an evident lag phase after the metabolite mixture application. A Trichoderma " $\mathrm{Ca}^{2+}$ signature" could be identified, which was characterized by a maximum of $\left[\mathrm{Ca}^{2+}\right]_{\text {cyt }}(6.09 \pm 0.11 \mu \mathrm{M})$, reached after about $1 \mathrm{~min}$, followed by a decrease within $20 \mathrm{~min}$ to $0.75 \pm 0.06 \mu \mathrm{M}$, without returning to resting values ( $100 \mathrm{nM})$ (Fig. 1a). No $\left[\mathrm{Ca}^{2+}\right]_{\text {cyt }}$ change was observed in control cells treated with the non-inoculated fungal culture medium (Fig. 1a). The Trichoderma metabolites were fractionated by using a $3 \mathrm{kDa}$ cut-off and the two separated fractions were applied to soybean cells. The resulting $\mathrm{Ca}^{2+}$ transients showed, after a first $\mathrm{Ca}^{2+}$ peak nearly superimposable in time, very different kinetic trends characterized by a slow and modulated pattern of signal dissipation with the $>3 \mathrm{kDa}$ fraction, and a rapid decline of the $\mathrm{Ca}^{2+}$ concentration to the basal level with the $<3 \mathrm{kDa}$ one (Fig. 1b). The combination of these two $\mathrm{Ca}^{2+}$ traces plus a plausible synergistic effect of the molecular components of the two fractions may account for the kinetics of the $\mathrm{Ca}^{2+}$ change observed with the unfractionated metabolite mixture (Fig. 1a).

In order to determine whether the Trichoderma $\mathrm{Ca}^{2+}$ signature is modified when the fungus is cultured with the pathogen $B$. cinerea, we tested metabolite mixtures produced by $B$. cinerea grown alone and during the coculture of these two fungi. Size-fractionated culture filtrates from the pathogenic fungus triggered in soybean cells $\mathrm{Ca}^{2+}$ changes characterized by special features, such as an exceptionally high $\mathrm{Ca}^{2+}$ elevation $(7.53 \pm 0.15 \mu \mathrm{M})$ caused by the $<3 \mathrm{kDa}$ metabolites, and a final long-lasting sustained $\mathrm{Ca}^{2+}$ level recorded with both $<3 \mathrm{kDa}(0.66 \pm 0.04$ $\mu \mathrm{M})$ and $>3 \mathrm{kDa}(0.47 \pm 0.03 \mu \mathrm{M})$ fractions (Fig. 1c). The $\mathrm{Ca}^{2+}$ transients observed upon cell treatment with both the fractions derived from Trichoderma cultured in the presence of Botrytis showed a single main $\mathrm{Ca}^{2+}$ peak occurring at different time values and, with the $<3 \mathrm{kDa}$ fraction, the persistence of a very high sustained plateau (about 9fold higher than the basal level) (Fig. 1d). It is noteworthy that different kinetics of the $\mathrm{Ca}^{2+}$ signals were generated in soybean cells by the co-application of the filtrates (both 

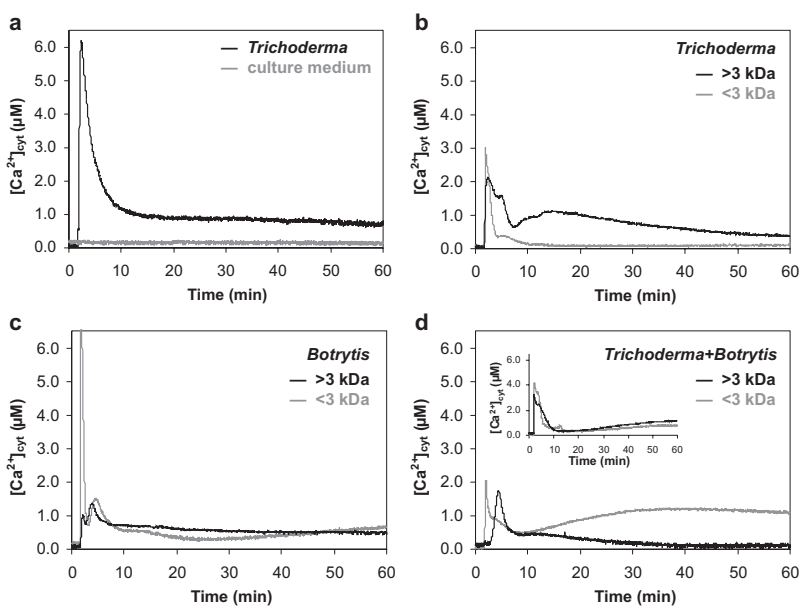

Figure I

Monitoring of $\left[\mathrm{Ca}^{2+}\right]_{c y t}$ in soybean cells challenged with fungal metabolite mixtures. Cells were treated with: the whole culture filtrate of Trichoderma (black trace) or non-inoculated culture medium (grey trace) (a); $>3 \mathrm{kDa}$ (black trace) and $<3 \mathrm{kDa}$ (grey trace) fractions from culture filtrates of Trichoderma (b), Botrytis (c), and Trichoderma grown in the presence of Botrytis (d). In c, the first peak of the $\mathrm{Ca}^{2+}$ transient induced by the $>3 \mathrm{kDa}$ metabolites is represented out of scale. In $d$, the inset shows the $\left[\mathrm{Ca}^{2+}\right]_{\text {cyt }}$ changes induced by the simultaneous application of the metabolite fractions (>3 kDa, black trace; <3 kDa, grey trace) from separately grown Trichoderma and Botrytis. Fungal filtrates were applied to cells after $100 \mathrm{~s}$. These and the following traces have been chosen to best represent the mean results from at least three repetitions.

$>3$ and $<3 \mathrm{kDa}$ ) from the two separately-grown fungi (Fig. $1 \mathrm{~d}$, inset) in comparison to the traces induced by those of the cocultured fungi (Fig. 1d). These results suggest that the antagonism condition modifies the quality/quantity of the molecules accumulated in the culture media and indicate that the presence of the phytopathogenic host may significantly affect the $\mathrm{Ca}^{2+}$ response of plant cells to Trichoderma.

\section{The lack of a Trichoderma specific endochitinase} modifies the kinetics of the $\mathbf{C a}^{2+}$ changes

The $>3 \mathrm{kDa}$ metabolite mixture from an endochitinase gene knock-out Trichoderma mutant, unable to produce the $42 \mathrm{kDa}$ endochitinase (CHIT42) [10], induced a $\mathrm{Ca}^{2+}$ transient clearly different from that of the wild type, both in the occurrence and level of the peaks. In addition, the $\mathrm{Ca}^{2+}$ signal dissipated almost completely within $10 \mathrm{~min}$ (Fig. 2a, compare with Fig. 1b). These findings suggest that CHIT42 is among the Trichoderma metabolites that may be perceived as elicitor by plant cells, and is likely to account for the sustained $\left[\mathrm{Ca}^{2+}\right]_{\text {cyt }}$ level over the time. The $<3 \mathrm{kDa}$ mixture produced by the Trichoderma $\Delta e c h 42$ mutant grown alone induced a $\mathrm{Ca}^{2+}$ trace that did not significantly differ from the wild type (Fig. 2a, compared with Fig. 1b). On the other hand, when the $\Delta e c h 42$ mutant was cocultivated with $B$. cinerea, also the $<3 \mathrm{kDa}$ metabolite mixture generated a $\mathrm{Ca}^{2+}$ profile quite different from the corresponding wild type fraction and more closely resembling the Botrytis-induced $\mathrm{Ca}^{2+}$ change (Fig. 2b, compared with Fig. 1c, d).

\section{Trichoderma metabolite mixtures elicit defense reactions in plant cells Intracellular ROS accumulation}

One of the earliest plant responses at the cellular level to fungal pathogen infection is an increased production of intracellular ROS [11]. Preliminary tests indicated that a time interval between 5 and 10 min after the treatment was optimal to measure intracellular ROS accumulation by using dichlorofluorescein diacetate (DCF) [12] (data not shown). Compared to control cells, that showed no fluorescence at all (Fig 3a'), both $>3$ and $<3 \mathrm{kDa}$ Trichoderma metabolite fractions induced a faint detectable signal (Fig. 3b' and 3f'). As expected in the case of a necrotrophic pathogen, Botrytis filtrates, mainly $<3 \mathrm{kDa}$, induced a level of fluorescence markedly higher (Fig. $3 c^{\prime}$ and $3 g^{\prime}$ ) than that of the biocontrol agent. ROS accumulation was very low when metabolites from Trichoderma cocultured with Botrytis were applied (Fig. 3d' and 3h'). In particular, in the case of the $<3 \mathrm{kDa}$ Trichoderma+Botrytis fraction (Fig. $\left.3 h^{\prime}\right)$ the significant reduction in DCF fluorescence may be attributed to the high percentage of dead cells $(60.4 \pm 1.8$ $\%$ after $10 \mathrm{~min}$ ) (see also below). No evident differences were found when cells were treated with filtrates of the $\Delta e c h 42$ mutant compared to the wild type (see for example Fig. $\left.3 e^{\prime}\right)$, unless the $<3 \mathrm{kDa}$ fraction of $\Delta e c h 42+$ Botrytis was applied (Fig. 3i', compared with 3h'). These findings indicate that, besides the generation of specific $\mathrm{Ca}^{2+}$ signatures, other processes are differentially affected by metabolites secreted by the phytopathogen and the biocontrol
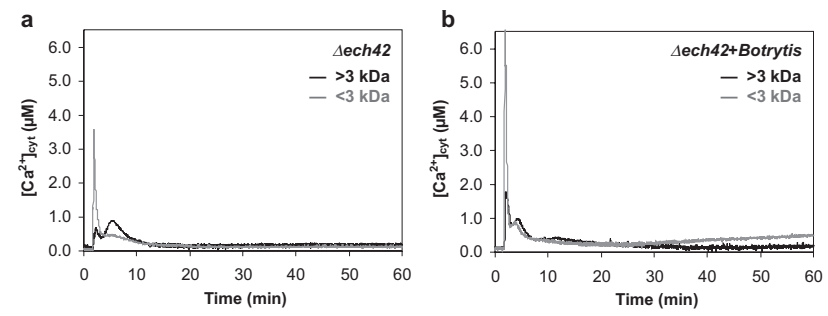

\section{Figure 2}

$\left[\mathrm{Ca}^{2+}\right]_{\text {cyt }}$ responses of soybean cells to metabolite mixtures secreted by the Trichoderma $\Delta$ ech42 mutant. Cells were treated with $>3 \mathrm{kDa}$ (black trace) or $<3$ $\mathrm{kDa}$ (grey trace) fractions of the metabolite mixtures secreted by the $\triangle$ ech 42 mutant, grown alone (a) or in the presence of Botrytis (b). 
agent. It can be speculated that the induction of ROS does not play a major role in the plant cell response to Trichoderma metabolite mixtures.

\section{Reduction in cell viability}

Intracellular $\mathrm{Ca}^{2+}$ overload may determine cytotoxicity and cause either apoptotic or necrotic cell death [13]. In view of the high levels of $\left[\mathrm{Ca}^{2+}\right]_{\mathrm{cyt}}$ induced by some of the fungal culture filtrates, their effect on cell viability was determined. Based on Evans Blue staining, all metabolite mixtures significantly increased after $30 \mathrm{~min}$ the percentage of dead cells in comparison with untreated controls, except the $>3 \mathrm{kDa}$ culture filtrate from the $\Delta e c h 42$ mutant (Fig. 4). The reduction in cell viability was more remarkable with $<3 \mathrm{kDa}$ mixtures (Fig. 4b) than $>3 \mathrm{kDa}$ (Fig. 4a), suggesting a major toxic effect played by low MW metabolites.
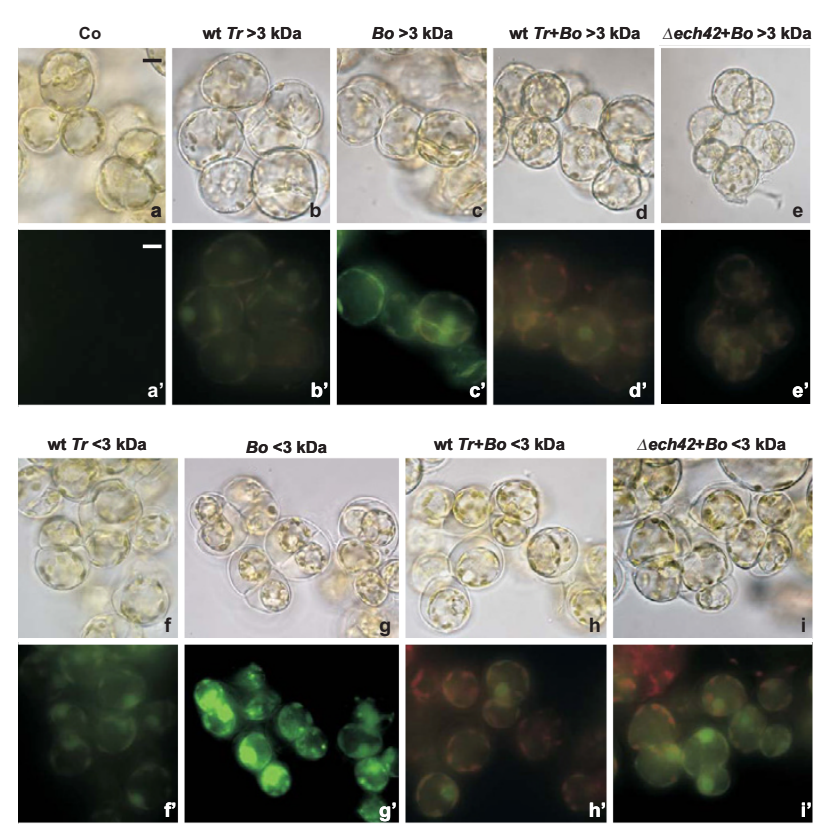

Figure 3

Detection of intracellular ROS accumulation in soybean cells treated with fungal culture filtrates. Intracellular ROS were detected by $\mathrm{H}_{2}$ DCF-DA staining in control cells (Co, a'), in cells treated with $>3 \mathrm{kDa}\left(\mathrm{b}^{\prime}-\mathrm{e}^{\prime}\right)$ and $<3 \mathrm{kDa}$ ( $\left.f^{\prime}-i^{\prime}\right)$ fractions of wild type Trichoderma (wt Tr, b'and f'), Botrytis (Bo, c'and $\left.g^{\prime}\right)$, the coculture of wild type Trichoderma and Botrytis (wt Tr+Bo, d' and h') and the coculture of Trichoderma $\Delta$ ech42 mutant and Botrytis ( $\Delta$ ech $42+B o$, e'and i'). For each treatment light (a-i) and fluorescence ( $\left.a^{\prime}-i^{\prime}\right)$ microscope images of the same field are presented. All images were acquired with the same exposition time gauged to the higher fluorescence emission intensity obtained with the Botrytis $<3$ $\mathrm{kDa}$ fraction. Pictures represent typical examples after 10 min treatment. Bar: $10 \mu \mathrm{m}$.
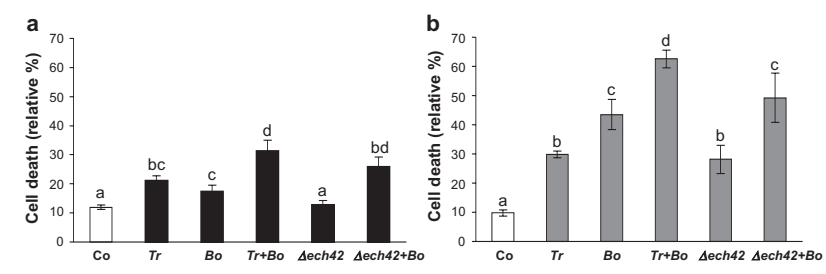

\section{Figure 4}

Changes in cell viability in response to fungal culture filtrates. Exponentially growing cells were incubated with $>3 \mathrm{kDa}$ (a, black boxes) and <3 kDa (b, grey boxes) fractions of the secreted fungal metabolite mixtures. Control cells (Co, white boxes) were incubated with culture medium only. All the abbreviations used for the treatments (wt $\operatorname{Tr}, \mathrm{Bo}, \Delta$ ech42) are as in Fig. 3. The $100 \%$ value correspond to cells treated for $10 \mathrm{~min}$ at $100^{\circ} \mathrm{C}$. Data are means \pm SD of three independent experiments. Bars labeled with a different letter differ significantly $(P<0.05)$ by Student's $t$ test.

\section{Induction of programmed cell death}

Detection of caspase activation, a strictly PCD-related event ([14] and references herein), was used to determine whether cell death induced by the fungal metabolite mixtures occurred via PCD rather than a necrotic event. In soybean control cells a low level of caspase 3-like activity, measured by quantification of free $\mathrm{p}$-nitroaniline $(0.018 \pm$ $0.002 \mathrm{mM}$ pNA), and probably due to normal cell turnover, was detected (Fig. 5a). In agreement with the results of the cell viability test, a significant increase of caspase 3like protease activity was caused by $30 \mathrm{~min}$ application of both $>3$ and $<3 \mathrm{kDa}$ metabolite mixtures obtained from Trichoderma wild type grown alone (Fig. 5a and 5b). This indicates that PCD is part of the plant cell response to Trichoderma metabolites. Interestingly, the $<3 \mathrm{kDa}$ fraction obtained from the Trichoderma-Botrytis coculture, although generating the maximal cell death percentage (Fig. 4b), was not found to trigger a significant caspase 3like activation (Fig. 5b), suggesting the induction of a different mode of cell death.

When cells were treated with the corresponding fraction of the $\Delta e c h 42$ Trichoderma mutant cocultured with Botrytis, a statistically significant activity of caspase 3-like protease was recorded, and this value $(0.038 \pm 0.004 \mathrm{mM}$ pNA $)$ approached that obtained with the $<3 \mathrm{kDa}$ Botrytis filtrate $(0.034 \pm 0.003 \mathrm{mM}$ pNA). In all experiments, the addition of a caspase 3 specific inhibitor (Ac-DEVD-CHO) lowered the amount of free pNA released from the substrate to the level of the control (data not shown), thus confirming the validity of the test for caspase 3-like activity. 

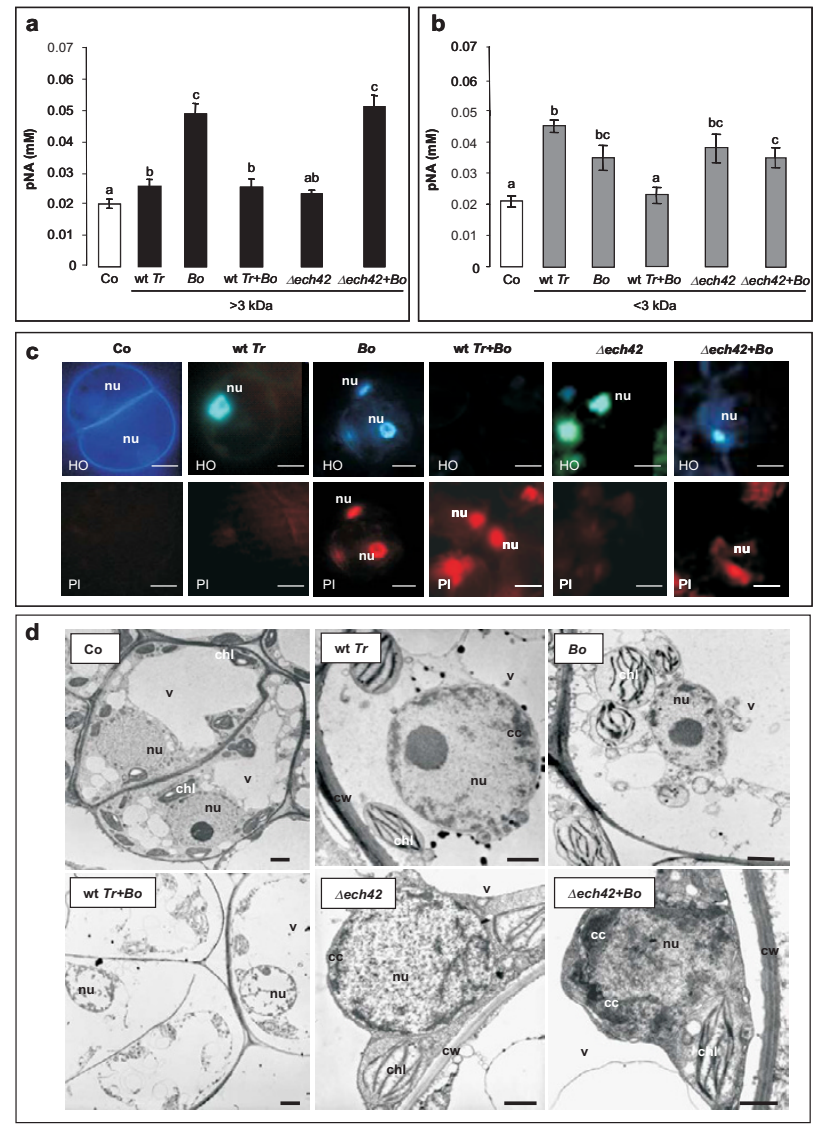

\section{Figure 5}

Effect of the fungal metabolite mixtures on caspase 3-like activity, chromatin condensation and ultrastructure of soybean cells. Panel a and b: caspase 3like activity in cells treated for 30 min with $>3 \mathrm{kDa}$ (a, black boxes) and $<3 \mathrm{kDa}$ (b, grey boxes) fractions of the metabolite mixtures. Control cells (Co, white boxes) were incubated with culture medium only. All the abbreviations used for the treatments (wt $T r, B o, \Delta$ ech42) are as in Fig. 3. Data are means $\pm S D$ of three independent experiments. Bars labeled with a different letter differ significantly $(P<0.05)$ by Student's $t$ test. Panel c: cells were treated with $<3 \mathrm{kDa}$ culture filtrates, stained with $\mathrm{HO}$ and $\mathrm{PI}$, and observed under a fluorescence microscope. Pictures represent typical examples. nu, nucleus. Bars: $5 \mu \mathrm{m}$. Panel d: ultrastructural observations of control cells and cells incubated for $15 \mathrm{~min}$ with $<3 \mathrm{kDa}$ fungal metabolites. cc, chromatin condensation, chl, chloroplast, cw, cell wall, nu, nucleus, $v$, vacuole. Bars: I $\mu \mathrm{m}$.

\section{Chromatin condensation and morphological cell alterations}

Hoechst 33342 (HO)/Propidium Iodide (PI) staining followed by morphological analysis provided additional information on the type of cell death caused by the fungal metabolite mixtures produced in all the considered experimental conditions. Fig. 5c shows the staining pattern of soybean cells incubated with the plasma membrane-per- meable DNA-binding agent $\mathrm{HO}$ and with the impermeant dye PI in the presence or absence of the $<3 \mathrm{kDa}$ fraction of the different fungal mixtures. Control cells had a faint or not detectable HO staining, with no evidence of chromatin condensation, and nuclei that did not stain with PI, indicating integrity of the plasma membrane. Electron microscope observations validated the healthy state of the cells (Fig. 5d). Cells treated with filtrates from Trichoderma wild type grown alone showed the prevalence of $\mathrm{HO}$ positive/PI negative nuclei, indicative of early PCD-like stages, characterized by chromatin condensation and an intact plasma membrane (Fig. 5c). Ultrastructural analyses confirmed these findings, showing small lumps of condensed chromatin close to an intact nuclear envelope and plasma membrane stuck to the cell wall in about $70 \%$ of the cells (Fig. 5d).

Most cells incubated with $<3 \mathrm{kDa}$ Botrytis metabolite mixture were HO positive/PI positive (late PCD stages), with both condensed chromatin and a functionally altered plasma membrane (Fig. 5c). Electron microscope observations indicated an evident chromatin condensation just beneath the nuclear envelope, chloroplasts and mitochondria altered in their organization, and plasma membrane detached from the cell wall (Fig. 5d).

The HO negative/PI positive staining pattern obtained with the $<3 \mathrm{kDa}$ metabolite mixture secreted in the coculture medium of the two fungal strains (Fig. 5c) revealed the absence of chromatin condensation and the breakdown of the plasma membrane, both characteristics of a necrotic status of the cells. The induction of a necrotic pathway was also supported by the lack of caspase 3-like activation (Fig. 5b). In the majority of the cells, the ultrastructure appeared deeply affected, with the plasma membrane completely detached and nuclei with a disorganized or absent nucleoplasm and heterogeneous residual chromatin clumps. Chloroplasts and mitochondria looked remarkably altered in their structure (Fig. 5d). Cell necrosis was somehow expected since during antagonism/ mycoparasitism T. atroviride strain P1 typically releases trichorzianines, $<3 \mathrm{kDa}$ secondary metabolites capable of directly killing cells by destructing the plasma membrane [15]. However, both the induction and effectiveness of these antibiotics require the action of endochitinases and other cell wall degrading enzymes on the host tissues, which explains the results obtained when the ech42 deletion mutant was used in the coculture instead of the wild type. In this case, the lack of the major chitinase activity may have reduced the induction and accumulation of the necrogenic metabolites, which resulted in a typical late PCD-like staining ( $\mathrm{HO}$ positive/PI positive) (Fig. 5c). This is confirmed by electron microscope observations, which likewise suggest a change in the induced cell death pathway (necrosis versus PCD) when wild type Trichoderma is 
replaced by the mutant strain in the dual coculture (Fig $5 d)$. No ultrastructural differences were found between treatments with $<3 \mathrm{kDa}$ metabolites produced by either Trichoderma wild type or $\Delta e c h 42$ mutant grown alone (Fig. $5 d)$.

\section{Discussion and Conclusion}

The aim of this study was to investigate how plants can sense the presence of a fungus able to effect plant disease control in the rhizosphere. As experimental system we used plant cell cultures which were challenged with Trichoderma metabolite mixtures. Moreover, possible modifications in the pattern of the secreted molecules were analysed by testing the effects of culture filtrates of Trichoderma growing in direct antagonism with the phytopathogenic fungus Botrytis. The use of suspension cultured plant cells as a simplified approach, although not closely mimicking the natural situation, offers several advantages in the dissection of complex cellular responses at a molecular level. These in vitro studies may represent a valuable starting point for future experiments to be carried out in planta.

The molecular nature of the elicitors produced by Trichoderma strains has been at least partially unravelled (see $[3,4]$ for reviews). Some of these compounds have been tested in purity for their ability to induce expression of plant defense genes and disease resistance [16,7]. However, the most direct way to have an overview of the complex reactions and effects caused by the fungal metabolites in plants is to assay the natural mixtures. Plants have been found to be actually penetrated and colonized by the fungus at the root level $[5,6]$, and thus the secreted fungal molecules directly interact with living plant cells. It is at the plant-fungus interface that the first steps of the molecular interaction occur and generate the multiple effects observed both in vitro and in agriculture conditions.

Our results highlight the induction of $\mathrm{Ca}^{2+}$-mediated signal perception as an early step during the interaction of soybean cells with Trichoderma metabolites. Although the involvement of $\mathrm{Ca}^{2+}$ in pathogen sensing by plants has been frequently claimed [17], to our knowledge a $\mathrm{Ca}^{2+}$ mediated perception by plant cells of a fungal biocontrol agent has not yet been reported. Since $\mathrm{Ca}^{2+}$ has been recently demonstrated to be involved also in the molecular communication between plant cells and mycorrhizal fungi [18], a transient variation in $\left[\mathrm{Ca}^{2+}\right]_{\mathrm{cyt}}$ proves once again to be the most general way for plants to open a dialogue with their fungal partners. The specificity of the $\mathrm{Ca}^{2+}$ changes that we recorded in the single and two-fungal partner interactions (pathogenic and antagonist fungus alone and in combination) guarantees that this intracellular messenger delivers to cells different messages, which are progressively decoded into definite downstream responses. A specificity of the perception mechanism by plant cells is confirmed by the fact that different patterns of intracellular ROS accumulation and cell death induction were determined by the application of the various fungal mixtures. This does not necessarily imply that the cascade of events leading to the physiological responses follows separate, independent pathways, but rather that a network of overlapping pathways may be activated $[19,20]$. In view of the complexity of signalling crosstalks, firm causal links among $\mathrm{Ca}^{2+}$, ROS and cell death are not easy to assess.

The fungal growth conditions used in this work are wellknown to induce the accumulation in the Trichoderma culture filtrates of specific compounds including enzymes, oligosaccharides and secondary metabolites. Separation of fungal culture filtrates by a $3 \mathrm{kDa}$ cut-off let us discriminate differential cell responses to the active molecules recovered in the two fractions.

The larger MW (>3 kDa) fraction is known to contain a battery of hydrolytic enzymes, released by Trichoderma [21-23] as well as Botrytis [24,25], capable of digesting the plant cell wall. Increasing evidence indicates that the elicitor function of fungal lytic enzymes is unrelated to their enzymatic activity, but instead due to the direct perception by plant cells of the protein per se, rather than just through their hydrolysis products [26-28].

The $<3$ kDa Trichoderma fraction includes, as major secondary metabolites, peptaibols such as trichorzianines $\mathrm{A}_{1}$ and $B_{1}[15]$, which are known to form oligomeric voltagedependent ion channels in the plasma membrane of fungal hosts and plant cells, thus affecting membrane permeability $[29,30]$; cell death may occur as a consequence of cytoplasmic leakage through these ion channels [31]. Oligosaccharides, gradually released by the action of Trichoderma hydrolytic enzymes on the fungal host cell wall, may also be active components of the small MW fraction generated in the two-way interaction (Trichoderma-Botrytis). They are perceived by both the biocontrol agent as mycoparasitism/antagonism inducers [32] and by plant cells as elicitors $[33,7]$. Chitooligomers have been demonstrated to activate in plant cells an increase in $\left[\mathrm{Ca}^{2+}\right]_{\mathrm{cyt}}$ $[34,35]$ and defense responses [33,36]. All the $<3 \mathrm{kDa}$ fractions tested were found to induce in plant cells effects on both $\mathrm{Ca}^{2+}$ changes and physiological parameters more remarkable than the higher MW mixtures. The enhancement of the cellular responses that we recorded upon cell treatment with the Trichoderma-Botrytis coculture filtrates cannot be attributed to the mere co-presence of elicitors released by the two fungi alone. Instead, qualitative/quantitative differences in the secreted compound mixture may arise when the biocontrol agent and the pathogen are grown together in direct antagonism, due to competition 
for nutrients and/or a direct effect of mycoparasitism $[7,38]$. Isolates of $T$. harzianum have been previously shown to reduce the activity of hydrolytic enzymes produced by B. cinerea [37]. Furthermore, the activity of Trichoderma hydrolytic enzymes gradually releases oligosaccharides from the Botrytis cell wall, which accumulate in the coculture medium. Our results indicate that plant cells are able to sense different elicitors that Trichoderma mainly addresses to its fungal host and consequently activate their own signal transduction pathway. This notion is also supported by recent findings concerning the activation in plants of a specific pattern of gene expression by the same Trichoderma strain [38].

Reduction in cell viability was recorded with all the metabolite mixtures of either Trichoderma or Botrytis. This result is expected for the pathogen, for which a $\mathrm{Ca}^{2+}$ - and caspase-mediated hypersensitive response (HR) has already been reported [39-41], but also not surprising for the biocontrol agent. It is a common finding that plant roots and seeds treated with Trichoderma are dotted with small necrotic spots probably caused by a HR, which results in localized callose deposition that limits the colonization of plant tissues by the fungus to the first few layers of cells [5,3].

The lack of the $42 \mathrm{kDa}$ endochitinase in the high MW fraction of the deletion mutant culture medium [10] determined a $\mathrm{Ca}^{2+}$ transient clearly different from that of the wild type. This result indicates that the knock-out of the ech42 gene and its effect on the molecules secreted in the culture medium deeply modifies the fungal signal which is perceived by plant cells through $\mathrm{Ca}^{2+}$. Furthermore, the inactivation of the ech 42 gene seems to produce, during the two-way interaction (Aech42-Botrytis), a $<3 \mathrm{kDa}$ metabolite mixture less necrogenic (in terms of ROS accumulation, activation of caspase 3-like protease and mode of cell death) than in wild type Trichoderma-Botrytis. This fraction is also able to induce a PCD pathway instead of a necrotic cell death, probably because of a reduced secretion of toxic secondary metabolites by the biocontrol agent. It has been demonstrated that the knock-out of the $42 \mathrm{kDa}$ endochitinase alters the biocontrol ability of Trichoderma virens [42] and reduces the mycoparasitic and disease control efficacy in vivo of T. atroviride strain P1 [10]. In addition, the ISR-inducing ability of the $\Delta e c h 42$ mutant is also lower than the wild type in assays where bean roots treated with Trichoderma are leaf-inoculated with $B$. cinerea (M. Lorito, unpublished). It has been previously demonstrated that complementation of the mutant culture filtrate with the purified $42 \mathrm{kDa}$ endochitinase fully recovers the Trichoderma biocontrol activity [10]. Application to plant cells of the unfractionated Trichoderma culture filtrate complemented with CHIT 42 may provide a useful validation of the results obtained in this paper. Nevertheless, in view of possible pleiotropic effects of the endochitinase deletion on the fungal metabolism, this experimental approach may lead to an oversimplification of the complex network of synergistic interactions between the Trichoderma bioactive molecules [43].

The changes in $\left[\mathrm{Ca}^{2+}\right]_{\mathrm{cyt}}$ triggered by Trichoderma metabolites in plant cells, although monitored only in vitro, provide new insight into the mechanisms by which these beneficial fungi affect plant physiology and resistance to stress. Our findings suggest the chance of using the Trichoderma secreted molecules, in mixtures or purified, as elicitor treatments against phytopathogens. This possibility is particularly intriguing, since a recognition of the biocontrol agent metabolites would allow the plant to perceive the presence of Trichoderma, thus pre-activating defense mechanisms against different pathogens [44], and also inducing a variety of other beneficial effects (i.e. promotion of plant growth, nutrient uptake, seed germination, resistance to abiotic stresses).

\section{Methods \\ Fungal strains, growth conditions and preparation of culture filtrates}

The wild type Trichoderma atroviride strain P1 [45] and its ech42 gene (encoding CHIT42 endochitinase) disruption mutant [10] were maintained at $25^{\circ} \mathrm{C}$ on potato dextrose agar (PDA) and as spore suspension in $10 \%$ glycerol at $40^{\circ} \mathrm{C}$. The Botrytis cinerea strain 319 was isolated from tobacco, grown at $25^{\circ} \mathrm{C}$ on malt extract agar and kept as a spore suspension in $10 \%$ glycerol at $-40^{\circ} \mathrm{C}$. Fungal starter cultures were obtained in potato dextrose broth at $25^{\circ} \mathrm{C}$, $150 \mathrm{rpm}$ for 3 days with light, collected by centrifugation, rinsed with sterile distilled water, and used to inoculate a salt medium [46] containing $0.1 \%(\mathrm{w} / \mathrm{v})$ sucrose and 0.1 $\%(\mathrm{w} / \mathrm{v})$ peptone. The cultures were grown at $25^{\circ} \mathrm{C}, 150$ $\mathrm{rpm}$, with light, for 3 days. Culture filtrates and the substrate alone, used as a control, were filter sterilized $(0.22$ $\mu \mathrm{m})$, concentrated by roto-evaporation approximately 20fold and fractionated with YM-3 MW (3000 Da cut-off) (Amicon Centriprep, Millipore) at $4000 \mathrm{rpm} 6^{\circ} \mathrm{C}$. The samples used as metabolite mixtures were: the whole concentrated filtrate, the fraction $>3000$ Da and that $<3000$ Da for each single fungus (Trichoderma, $\Delta e c h 42$ mutant, Botrytis), plus the extracts of $\mathrm{P} 1$, or the $\Delta e c h 42$ mutant, grown in the presence of Botrytis. For plant cell treatments, fungal culture filtrates were lyophilized and resuspended in plant cell culture medium. The final dose applied to cells corresponded to 4 -fold concentrated fungal medium.

\section{Plant cell cultures}

Cell suspension cultures of soybean (Glycine max L., line 6.6.12) stably expressing cytosolic aequorin were maintained as described by [34]. Cell treatments with fungal 
culture filtrates were performed two weeks after reinoculation, during the exponential growth phase of the cells.

\section{Aequorin-dependent $\mathrm{Ca}^{2+}$ measurements}

In vivo reconstitution of aequorin and $\mathrm{Ca}^{2+}$ measurements were carried out as previously described [18].

\section{Intracellular ROS detection}

Intracellular production of reactive oxygen species (ROS) was measured according to [12], by loading the cells with $15 \mu \mathrm{M} \quad 2^{\prime}, 7^{\prime}$ - dichlorodihydrofluorescein diacetate $\left(\mathrm{H}_{2}\right.$ DCF-DA, Molecular Probes, Leiden, The Netherlands). This non polar compound is actively taken up by cells and converted by esterases in $\mathrm{H}_{2} \mathrm{DCF}$, a non fluorescent molecule, which is rapidly oxidized to the highly fluorescent DCF by intracellular peroxides. Treatments with fungal culture filtrates were carried out $10 \mathrm{~min}$ after dye loading and extensive washing. DCF was excited at 488 $\mathrm{nm}$ and emitted fluorescence was detected through a 520 bandpass filter. Cells were observed within $10 \mathrm{~min}$.

\section{Cell viability}

Cell viability was determined, after 30 min treatment with the fungal culture filtrates, by the Evans Blue method [47].

\section{Caspase 3-like activity}

Caspase 3-like activity was measured, after $30 \mathrm{~min}$ cell treatment, using the "caspase- 3 colorimetric activity assay kit" (Chemicon International, Inc., Temecula, CA), as previously described [26] by quantification of free pnitroaniline (pNA) released by the enzymatic cleavage of the caspase 3 synthetic substrate Ac-DEVD-pNA.

\section{Hoechst 33342 (HO) and Propidium lodide (PI) staining}

After 30 min treatment with the different fungal culture filtrates, cells were incubated for $10 \mathrm{~min}$ in darkness with $8 \mu \mathrm{g} / \mathrm{ml} \mathrm{HO}$ and $5 \mu \mathrm{g} / \mathrm{ml}$ PI (Sigma-Aldrich, St. Louis, USA) at room temperature. Cells were observed using a fluorescence microscope with an excitation light of 350 $\mathrm{nm}$ and $570 \mathrm{~nm}$ for $\mathrm{HO}$ and PI, respectively.

\section{Transmission electron microscopy}

Cells were collected after $15 \mathrm{~min}$ treatment and processed as previously described [48].

\section{Statistical analysis}

Data were expressed as mean \pm S.D. The statistical significance of differences $(P<0.05)$ between means was evaluated using Student's $t$ test.

\section{Authors' contributions}

LN carried out $\mathrm{Ca}^{2+}$ measurement assays and participated in drafting and editing the manuscript. BB carried out ROS detection, viability assays and electron microscope observations. RM maintained plant cell cultures and partici- pated in the $\mathrm{Ca}^{2+}$ measurement assays. $\mathrm{AZ}$ carried out the $\mathrm{HO} / \mathrm{PI}$ test and caspase-3 like activity analysis. SW maintained fungal cultures, prepared and fractionated fungal metabolite mixtures and revised English language of the manuscript. PM participated in the design and coordination of the study, drafted the manuscript and participated in its editing. ML conceived of the study and helped to draft and edit the manuscript. All authors read and approved the final manuscript.

\section{Acknowledgements}

We thank G. Neuhaus (Institut für Biologie II, Zellbiologie, Freiburg, Germany) for kindly providing aequorin-expressing soybean cell cultures. This work was supported by FIRB 2002 prot. RBNEOIK2E7, PRIN 2003 prot. 20030707I9, MIUR-PON 12935; MIUR-PON DDI2 19; MIUR-PON DDI80I; EU TRICHOEST; EU 2E-BCAs.

\section{References}

I. Punja ZK, Utkhede RS: Using fungi and yeasts to manage vegetable crop diseases. Trends Biotechnol 2003, 2 I (9):400-407.

2. Benítez T, Rincón AM, Limón MC, Codón AC: Biocontrol mechanisms of Trichoderma strains. Int Microbiol 2004, 7(4):249-260.

3. Howell CR: Mechanisms employed by Trichoderma species in the biological control of plant diseases: the history and evolution of current concepts. Plant Dis 2003, 87(I):4-I0.

4. Harman GE, Howell CR, Viterbo A, Chet I, Lorito M: Trichodermo species - opportunistic, avirulent plant symbionts. Nat Rev Microbiol 2004, 2(I):43-56.

5. Yedidia I, Benhamou N, Chet I: Induction of defense responses in cucumber plants (Cucumis sativus L.) by the biocontrol agent Trichoderma harzianum. Appl Environ Microbiol 1999 , 65(3): $1061-1070$.

6. Bolwerk A, Lugtenberg BJJ, Lorito M, Bloemberg GV: Biocontrol of tomato foot and root rot by Trichoderma. MolPlant-Microbe Interact 2007 in press.

7. Woo SL, Scala F, Ruocco M, Lorito M: The molecular biology of the interactions between Trichoderma, phytopathogenic fungi and plants. Phytopathology 2006, 96(2): $181-185$.

8. Scheel D: Resistance response physiology and signal transduction. Curr Opin Plant Biol 1998, I(4):305-310.

9. Sanders D, Pelloux J, Brownlee C, Harper JF: Calcium at the crossroads of signaling. Plant Cell 2002, I 4(Suppl):S40I-S4I7.

10. Woo SL, Donzelli B, Scala F, Mach R, Harman GE, Kubicek CP, Del Sorbo G, Lorito M: Disruption of the ech42 (endochitinaseencoding) gene affect biocontrol activity in Trichoderma harzianum PI. Mol Plant-Microbe Interact 1999, I 2(5):419-429.

II. Mittler R, Vanderauwera S, Gollery M, Breusegem FV: Reactive oxygen gene network of plants. Trends Plant Sci 2004, 9( I 0):490-498.

12. Maxwell DP, Wang Y, Mclntosh L: The alternative oxidase lowers mitochondrial reactive oxygen production in plant cells. Proc Natl Acad Sci USA 1999, 96(14):827I-8276.

13. Orrenius S, Zhivotovsky B, Nicotera P: Regulation of cell death: the calcium-apoptosis link. Nat Rev Mol Cell Biol 2003, 4(7):552-565

14. Woltering EJ, Van Der Bent A, Hoeberichts FA: Do plant caspases exist? Plant Physiol 2002, I30(4): I764-I769.

15. Schirmböck M, Lorito M, Wang YL, Hayes CK, Arisan-Atac I, Scala F, Harman GE, Kubicek CP: Parallel formation and synergism of hydrolytic enzymes and peptaibol antibiotics, molecular mechanisms involved in the antagonistic action of Trichoderma harzianum against phytopathogenic fungi. Appl Environ Microbiol 1994, 60( I 2):4364-4370.

16. Djonović S, Pozo MJ, Dangott LJ, Howell CR, Kenerly CM: SmI, a proteinaceous elicitor secreted by the biocontrol fungus Trichoderma virens induces plant defense responses and systemic resistance. Mol Plant-Microbe Interact 2006, 19(8):838-853.

17. Lecourieux $D$, Ranjeva $R$, Pugin $A$ : Calcium in plant defence-signalling pathways. New Phytol 2006, I 1 I (2):249-269.

18. Navazio L, Moscatiello R, Genre A, Novero M, Baldan B, Bonfante P, Mariani $P$ : A diffusible signal from arbuscular mycorrhizal 
fungi elicits a transient cytosolic calcium elevation in host plant cells. Plant Physiol 2007, I44(2):673-68I.

19. Shinozaki K, Dennis ES: Cell signalling and gene regulation: global analyses of signal transduction and gene expression profiles. Curr Opin Plant Biol 2003, 6(5):405-409.

20. Garcia-Brugger A, Lamotte $O$, Vandelle E, Bourque $S$, Lecourieux $D$, Poinssot $B$, Wendehn $D$, Pugin $A$ : Early signaling events induced by elicitors of plant defenses. Mol Plant-Microbe Interact 2006 19(7):7II-724.

21. Markovich NA, Kononova GL: Lytic enzymes of Trichoderma and their role in plant defense from fungal diseases: a review. Appl Biochem Microbiol 2003, 39(4):34I-35I.

22. Hanson LE, Howell CR: Elicitors of plant defense responses from biocontrol strains of Trichoderma virens. Phytopathology 2004, 94(2): $17|-| 76$

23. Suárez MB, Vizcaíno JA, Llobell A, Monte E: Characterization of genes encoding novel peptidases in the biocontrol fungus Trichoderma harzianum CECT 2413 using the TrichoEST functional genomics approach. Curr Genet 2007, 5 I (5):33 I-342.

24. Staples RC, Mayer AM: Putative virulence factors of Botrytis cinerea acting as a wound pathogen. FEMS Microbiol Lett 1995 134(1): I-7.

25. Tiedemann AV: Evidence for a primary role of active oxygen species in induction of host cell death during infection of bean leaves with Botrytis cinerea. Physiol Mol Plant Pathol 1997, 50(3): $15 \mid-166$.

26. Sharon A, Fuchs Y, Anderson JD: The elicitation of ethylene biosynthesis by a Trichoderma xylanase is not related to the cell wall degradation activity of the enzyme. Plant Physiol 1993, 102(4): 1325-1329.

27. Poinssot B, Vandelle E, Bentéjac M, Adrian M, Levis C, Brygoo Y, Garin J, Sicilia F, Coutos-Thévenot P, Pugin A: The endopolygalacturonase I from Botrytis cinerea activates grapevine defense reactions unrelated to its enzymatic activity. Mol Plant-Microbe Interact 2003, 16(6):553-564.

28. Zuppini A, Navazio L, Sella L, Castiglioni C, Favaron F, Mariani P: An endopolygalacturonase from Sclerotinia sclerotiorum induces $\mathrm{Ca}^{2+}$-mediated signaling and programmed cell death in soybean cells. Mol Plant-Microbe Interact 2005, I 8(8):849-855.

29. Engelberth J, Koch T, Schüler G, Bachmann N, Rechtenbach J, Boland $\mathrm{W}$ : Ion channel-forming alamethicin is a potent elicitor of volatile biosynthesis and tendril coiling. Cross talk between jasmonate and salicylate signaling in lima bean. Plant Physiol 200I, I 25(I):369-377

30. Degenkolb T, Berg A, Gams W, Schlegel B, Gräfe U: The occurrence of peptaibols and structurally related peptaibiotics in fungi and their mass spectrometric identification via diagnostic fragment ions. J Pept Sci 2003, 9(I I-I 2):666-678.

3I. Chugh JK, Wallace BA: Peptaibols: models for ion channels. Biochem Soc Trans 200I, 29(4):565-570.

32. Zeilinger S, Galhaup C, Payer K, Woo SL, Mach RL, Fekete C, Lorito $M$, Kubicek CP: Chitinase gene expression during mycoparasitic interaction of Trichoderma harzianum with its host. Fungal Genet Biol 1999, 26(2): | 31-40.

33. Repka V: Elicitor-stimulated induction of defense mechanisms and defense gene activation in grapevine cell suspension cultures. Biol Plant 200I, 44(4):555-565.

34. Mithöfer A, Ebel J, Bhagwat AA, Boller T, Neuhaus-Url G: Transgenic aequorin monitors cytosolic calcium transients in soybean cells challenged with $\beta$-glucan or chitin elicitors. Planta 1999, 207(4):566-574.

35. Müller J, Staehelin C, Xie ZP, Neuhaus-Url G, Boller T: Nod factors and chitooligomers elicit an increase in cytosolic calcium in aequorin-expressing soybean cells. Plant Physiol 2000, I 24(2):733-739.

36. Ning W, Chen F, Mao B, Li Q, Liu Z, Guo Z, He Z: N-acetylchitooligosaccharides elicit rice defence responses including hypersensitive response-like cell death, oxidative burst and defence gene expression. Physiol Mol Plant Pathol 2004, 64(5):263-27I.

37. Kapat A, Zimand G, Elad Y: Effects of two isolates of Trichoderma harzianum on the activity of hydrolytic enzymes produced by Botrytis cinerea. Physiol Mol Plant Pathol I998, 52(2): I27-I37.

38. Marra R, Ambrosino P, Carbone V, Vinale F, Woo SL, Ruocco M, Ciliento R, Lanzuise S, Ferraioli S, Soriente I, Gigante S, Turrà D, Fogliano $\mathrm{V}$, Scala F, Lorito M: Study of three-way interaction between
Trichoderma atroviride, plant and fungal pathogens by using a proteomic approach. Curr Genet 1998, 50(5):307-321.

39. Govrin EM, Levine A: The hypersensitive response facilitates plant infection by the necrotrophic pathogen Botrytis cinerea. Curr Biol 2000, I0(13):75I-757.

40. Hoeberichts FA, ten Have A, Woltering EJ: A tomato metacaspase gene is upregulated during programmed cell death in Botrytis cinerea -infected leaves. Planta 2003, 21 7(3):517-522.

4I. Van Baarlen P, Staats M, Van Kan AL: Induction of programmed cell death in lily by the fungal pathogen Botrytis elliptica. Mol Plant Pathol 2004, 5(6):559-574.

42. Baek JM, Howell CR, Kenerley CM: The role of an extracellular chitinase from Trichoderma virens Gv29-8 in the biocontrol of Rhizoctonia solani . Curr Genet I999, 35(I):4I-50

43. Lorito M, Woo SL D'Ambrosio M, Harman GE Hayes CK, Kubicek $\mathrm{CP}$, Scala F: Synergistic interaction between cell wall degrading enzymes and membrane affecting compounds. Mol PlantMicrobe Interact 1996, 9(3):206-213.

44. Prime-A-Plant Group: Priming: Getting ready for battle. Mol Plant-Microbe Interact 2006, I 9(10): I062-107I.

45. Tronsmo A: Biological and integrated controls of Botrytis cinerea on apple with Trichoderma harzianum. Biol Control |99|, I(I):59-62.

46. Lorito M, Hayes CK, Di Pietro A, Woo SL, Harman GE: Purification, characterization and synergistic activity of a glucan I,3B-glucosidase and an $\mathbf{N}$-acetyl-B-glucosaminidase from Trichoderma harzianum. Phytopathology 1994, 84(4):398-405.

47. Baker CJ, Mock NM: An improved method for monitoring cell death in cell suspension and leaf disc assays using Evans Blue. Plant Cell Tissue Organ Cult 1994, 39(1):7-I2.

48. Zuppini A, Baldan B, Millioni R, Favaron F, Navazio L, Mariani P: Chitosan induces $\mathrm{Ca}^{2+}$-mediated programmed cell death in soybean cells. New Phytol 2004, 16 I (2):557-568.

Publish with Biomed Central and every scientist can read your work free of charge

"BioMed Central will be the most significant development for disseminating the results of biomedical research in our lifetime. "

Sir Paul Nurse, Cancer Research UK

Your research papers will be:

- available free of charge to the entire biomedical community

- peer reviewed and published immediately upon acceptance

- cited in PubMed and archived on PubMed Central

- yours - you keep the copyright 